\title{
Dynamics of Risking Sex and Sufistic Counseling at College Students in Semarang
}

\author{
Heri Saptadi Ismanto ${ }^{1}$, \\ ${ }^{1}$ Corresponding author, Semarang PGRI University \\ Anwar Sutoyo ${ }^{3}$ \\ ${ }^{3}$ Doctoral Program Semarang State University \\ Campus of Sekaran Gunung Pati Semarang, Indonesia
}

\author{
Sugiyo $^{2}$ \\ ${ }^{2}$ Doctoral Program Semarang State University \\ Campus of Sekaran Gunung Pati Semarang, Indonesia \\ Soesanto $^{4}$ \\ ${ }^{4}$ Doctoral Program Semarang State University \\ Campus of Sekaran Gunungpati Semarang, Indonesia
}

\begin{abstract}
The objectives of this study were: (1) to describe the dynamics of students having risky sex behavior, (2) to describe sufistic counseling to help students not to engage in risky sex behavior. This study used a qualitative research method with a phenomenological approach to describe the values of Sufism in counseling students with risky sexual behavior. Data collection was carried out by observation, interviews, questionnaires and documentation. The results showed 1) the dynamics of students with risky sex behavior was explained by the subject's data in general, the level of religiosity was low. This is a problem faced in adolescence, namely the transition period which makes adolescent emotions less stable; 2) Sufism values in counseling are a concept of scientific counseling services that are required to be more humanistic, empirical and functional (appreciation of Islamic teachings). This counseling discusses and discusses how to build the morale of the people. Sufism counseling method begins with a futuwwah framework by applying the ascetic attitude towards the world of macrocosm and microcosm (human).
\end{abstract}

Keyword:- Dinamic, Counseling, Sufism, Risky Sexual Behavior

\section{INTRODUCTION}

The phenomenon of increasing HIV / AIDS sufferers also occurred in Semarang City. The number of HIV-AIDS cases in Semarang City reaches hundreds of new cases in a year, which are detected by the Semarang City Health Office (Dinkes). According to data from the Semarang City Health Office, the total number of people with HIV-AIDS in Semarang has reached 5,228 people from 2017 to March 2019. Head of the Semarang City Health Office, Widoyono said, on average every year in Semarang City, 500 new sufferers are found (Fajlin, 2019). The number of HIV / AIDS cases is an iceberg phenomenon, because the number of cases caught is only 20 percent. If the assumption of this iceberg phenomenon is correct, it means that so far there have been more than 20,800 cases of HIV / AIDS in Semarang City. The growth of HIV / AIDS cases in Semarang City is due to a number of factors, including drinking alcoholic drinks, free sex, changing partners, and sex with the same sex.

The existence of HIV cases was triggered by risky sexual behavior that many students practiced. Unhealthy environmental conditions, rampant viewing of pornography and porno-action on social media, television and Video Compact Disk (VCD) or Digital Video Disk (DVD), abuse of contraceptives and illegal drugs, disharmony in family life, and moral decadence of adults greatly affects the counselee's behavior pattern or lifestyle. Likewise, the rise of students with risky sexual behavior is a new phenomenon in people's lives. In line with that, there has been an increase in HIV / AIDS sufferers who have become endemic. The phenomenon of students having risky sexual behavior in the city of Semarang is a phenomenon that is considered a behavior that deviates from the norms that apply in society, but this behavior still exists and continues to occur. This requires a solution in order for the deviant behavior to improve. Students need guidance to be able to identify themselves from this behavior. Sexual behavior is said to be risky if the behavior brings unwanted consequences such as abortion, pregnancy outside of marriage, sexually transmitted diseases (STDs), and HIV / AIDS. Risky sexual behavior causes negative impacts on the lives of adolescents (Chandra, Rahmawati \& Hardiani, 2014).

There have been various studies on risky sexual behavior. Brînzeu and Szönyi (2011) explain that esotericism is usually associated with secret systems of thought, usually of a syncretic character, associating religious enlightenment programs (eg Gnosticism, or Pietism) and more practical forms of knowledge (alchemy, astrology). Birthrong (2013) wrote a study showing that low self-control provides a general risk while the tendency for impulsive behavior in the context of intense emotions gives more specific risks such as for various types of risky sexual behavior. Barjat (2020) shows that health students' knowledge has poor knowledge about STIs and STI prevention, and risky behavior. This is necessary to provide good training on IMS to HS. Therefore, deviant sexual behavior must be reduced and even avoided, especially morals for the younger generation. 
This effort can be done by providing Islamic-based counseling. The basis of counseling is the starting point for moving towards the desired goal, namely an effort that is running well, structured, and directed. Islamic Guidance and Counseling is a business that has the main basis based on the provisions of the al-Qur'an and as-Sunnah, both of which are the source of guidance for the life of Muslims. Sufism is basically a path or means taken by a person to know the behavior of lust and the qualities of lust, both bad and praiseworthy. Therefore, the position of Sufism in Islam is recognized as a religious knowledge that deals with moral aspects and behavior which are the substance of Islam. Where in philosophy Sufism was born from one of the basic components of Islam, namely Iman, Islam, and Ihsan. If faith gave birth to knowledge of theology, Islam gave birth to knowledge of syari'at, then ihsan gave birth to knowledge of morals or tasawuf (Syukur, 2001: 112).

In the world of Sufism, the presentation of conceptual problems in Islam, such as: repentance, zuhud, wara ', patience, gratitude, pleasure, sincerity, muraqabah, muqarabah, mahabbah, ma'rifah and others contained in Maqamat and Ahwal always try to be realized by looking at the situation and conditions contextually. Students in learning Sufism Morals are always treated to conceptual materials as above, then given examples of demonstration strategies, analogies and their rivals. For example, repentance. Repentance is basically 4 (four), namely consciousness (consciousness), Confession (al-I'tiraf), (alNadam (regret), Commitment, and Changes in Behavior (trying to do good continuously). Psychologically, these five basic principles of repentance are part of the psychological dynamics in humans (Suyuti, 2002: 3).

Sufism values in counseling are actually a scientific counseling concept that is required to be more humanistic, empirical and functional (appreciation of Islamic teachings). So that this counseling discusses and discusses how to build the morale of the people. The application of Sufism values in counseling leads to a constructive one, both concerning personal and social life. When a society has been exposed to what is called alinasi (alienation) disease due to the process of development and modernization, that's when they need deep spiritual (esoteric) guidelines or basic life to maintain the integrity of their personality. Counseling as a helping profession is a concept that underlies the role and function of counselors in today's society. Helping profession is a profession whose members are specially trained and have a license or certificate for a unique service and are needed by the community as the only professional provider for the unique and needed services they offer (Gibson and Michell, 2010: 43).

This study seeks to understand the Sufism values of Muslim students who have risky sexual behavior. Basically the students having risky sexual behavior do not know Sufism. The perpetrators only know that Sufism as a branch of science in Islam is scientifically the result of Islamic culture that was born after the death of the Prophet. They do not understand that the root of their thought, that Sufism comes from the concept of Ihsan. Ihsan itself is all Muslim behavior, both physical and mental, in worship and muamalah. Ihsan is the soul or spirit of faith and Islam (Syukur, 2004: 3).

There are several notes on the importance of Sufism in the dimensions of modern human life in students having risky sexual behavior. Brief conclusions that can be noted include: first, Sufism is a natural basis for every human being. It is a divine potential that serves to design human history and civilization. Sufism can color all activities both in social, political, economic and cultural dimensions. Second, Sufism functions as a means of controlling and controlling humans, so that the human dimension is not tarnished by modernization that leads to moral decadence and value anomalies, so that Sufism will lead people to achieve supreme morality. Third, Sufism has relevance and significance to the problems of modern humans, because Sufism has equally provided inner coolness and sharia discipline. It can be understood as a form of behavior through the Sufism suluki approach and can satisfy intellectual thirst through the philosophical taswuf approach. It can be practiced by every Muslim, from any social level and in any place. Physically they face one direction, namely the ka'bah, and spiritually they are competing to take the path (tarekat) through maqamat and ahwal towards the closeness (qurb) with God Almighty (Solihin, 2005: 5).

The objectives of study were (1) to describe the dynamics of students having risky sex behavior, (2) to describe sufistic counseling to help students not to engage in risky sex behavior.

\section{LITERATURE REVIEW}

\section{$>$ Risk Sexual Behavior}

Behavior is a form of response or reaction to external disturbances, but the response given depends on the characteristics or factors that the person has (Luthviatin, et al, 2012). Sex is a life instinct whose main function is procreation or regeneration and pleasure or enjoyment. However, humans with the potential to think about themselves distort the function of sex and, unfortunately, in expressing sexual behavior, they are not subject to the order of aqidah and rules, do not refer to the terms and laws and also do not compensate with proper order and guidance, aspects of human thought and imagination should guide sexual instinct towards higher and higher human values, namely the expression of religious, healthy and ethical love. (Hambali, 1998).

Adolescent sexual behavior coincides with sexual maturity. The emergence of sexual urges, namely being attracted to the opposite sex, is often referred to as lust. In this situation, teenagers are challenged not to have sexual intercourse. Sarwono (2000) states, our culture does not allow sexual relations outside of marriage. Whereas marriage usually requires tough conditions and can only be done after a few years after adolescence. Because of this, teenagers are forced to seek fulfillment in fantasies, read 
books or watch obscene films and so on, which often make it difficult for parents, teachers and other educators. Sexual behavior is all human behavior that is driven by sexual desire, both with the opposite sex and with the same sex (Sarwono, 2011). Meanwhile, sexual behavior is said to be risky if the behavior brings unwanted consequences such as abortion, pregnancy outside of marriage, sexually transmitted diseases (STDs), and HIV / AIDS. Risky sexual behavior causes negative impacts on the lives of adolescents (Chandra, Rahmawati \& Hardiani, 2014). Dating, kissing lips and having sexual intercourse are examples of risky sexual behavior that can have a negative impact on the perpetrator (Sarwono, 2011). As a result of this risky sexual behavior, not a few teenage boys suffer from venereal diseases and for women generally experience feelings of trauma to depression and are dangerous for their reproductive organs (Kasim, 2014).

Risk sex behavior is sexual relations both heterosexual (different sexes), homosexual (same sex), bisexual (same sex or opposite sex) and vaginal (through intercourse), oral (through mouth) or anal (through the anus / rectum) with partners who have no known sexual history or with partners who are not permanent / multiple partners, especially if not using a protector / condom.

\section{$>$ Sufistic Counseling}

Counseling is an art that is used in an effort to constructively change someone's behavior. The goal of counseling is emotional and emotional, not intellectual. Meanwhile, Sufistik means Sufism. In this case, what is meant by Sufism is the value of Sufism, as taught by the Sufis.

Sufistic counseling is a counseling model based on the teachings of Sufism. Sufism is part of the three pillars of Islam (Iman, Islam and Ihsan), in which Sufism rests on the pillars of Ihsan. The application of al-Ihsan is based on the concept of worship, "it is as if seeing Allah and believing that Allah sees what His servants are doing.

The general principle of sufistic counseling guidance is that guidance and counseling are efforts to direct a person to a better direction. This direction is suggestive by pointing out the facts of the cause and effect of what individuals do. This is the same as the principles of the Prophets and Apostles in carrying out prophetic and apostolic mandates. In principle, it is just conveying. The case is then accepted or not, all return to the counselee, so that it is not in the form of an order or patronizing, but only gives a picture. Its particular principle is in accordance with service goals, individual problems, service programs, and service implementation, all of which are directed in order to change individual negative behavior for the better.

Sufism in counseling in this study carries the values of modern Sufism. According to Damami, the term modern Sufism is the opposite of traditional Sufism. The Sufism offered by Hamka is based on the principle of tauhid, not the search for the experience of mukasyafah; the way of Sufism through zuhud attitudes that can be carried out in official worship. The ascetic attitude does not need to remain lonely by staying away from normal life; his appreciation of Sufism is in the form of a dynamic piety experience, not wanting to "unite with God" (unitive state); and his Sufism reflection is in the form of showing the heightened social sensitivity of the Sufi (also called "karamah in the socio-religious sense") not because he wants to get "karamah" which is magical, metaphysical and the like (Damami, 2000: 243).

Sufism in counseling also examines Hamka's thoughts in the field of Sufism, namely the basic concept offered, namely "forward" oriented Sufism which is characterized by the mechanism of a system of ketasawufan whose elements include the principle of tauhid, in the sense of maintaining God's transcendence and feeling at the same time. close to God.". And utilizing worship as a medium for tasawuf, in the sense that in addition to carrying out religious orders, it is also looking for wisdom in the form of a positive attitude towards life in the form of having a high social ethos (Damami, 2000: 243-244).

Sufism is both contextual and normative. Sufism cannot escape contextuality and normativity. If Sufism is not contextual, it will not be useful for society at a certain time and place; and if it is not normative, then Sufism will not only maintain the status quo, but also will not inspire people to live their lives. So, creative Sufism is nothing but the human response to his changing life created by God.

\section{METHOD}

This study uses a qualitative approach that produces descriptive data in the form of written and or spoken words from people and observable behavior (Moleong, 2007: 4). This research uses qualitative research methods with a phenomenological approach. The use of this method is based on the reason that the focus in this study is Sufistic counseling by applying Sufism values in counseling students with risky sexual behavior. So here the researcher wants to know the meaning of the experiences experienced by students having risky sexual behavior related to the values of Sufism in counseling through this phenomenological study.

This qualitative research design uses a phenomenological study. The focus of this study is limited to two things, namely the implications of Sufism values in counseling and risky sexual behavior. The data obtained in this study are qualitative data. These data provide an overview of the implications of Sufism values in counseling to prevent risky sexual behavior in students with risky sexual behavior, the counseling process that has been implemented, and the output achieved from the counseling process that has been implemented. The data obtained in this study included data on students having risky sexual behavior. The output data of Sufism values in counseling students with risky sexual behavior. 
The data source of the research in this research is that students have risky sexual behavior among students in Semarang, which is related to the values of Sufism in counseling to prevent risky sexual behavior in Muslim individuals. The data collection instruments in this study were (1) interviews; (2) Observation, (3) documentation. Sufistic counseling in this case must be done with a Sufism approach. One of the most important approaches to Sufism is the heart approach (from heart to heart). Students are invited to think and feel. At this stage it's still logical, but it makes sense. This is done, so that students continue to use their rationality, to then be directed to the spiritual realm. The next stage, then logic is filled with psychological awareness. The stage above is the counseling stage, then the guidance stage. In the guidance stage, students must be directed to a step-by-step process

\section{RESULT AND DISCUSSION}

\section{* The Psychological Dynamics of Sex Offenders aAt Risk Risky Sexual Behavior Causes Negative Impacts on Adolescent Life.}

The psychological dynamics of research subjects are illustrated by the following research.

\section{$>$ The Subject of Risk Sex Behavior}

Respondents between the ages of 22-25 years, namely: H.E (25 years), M.R (23 years), and S.M.D (22 years). The three respondents had gone through puberty at the age of 15-16 years. Puberty in their lives begins at the age of 11 to 12 years and ends at around 15 to 16 years of age. At that time growth and development took place rapidly. Puberty in women is marked by the first menstruation (menarche), while in men it is characterized by wet dreams. Now, there is known early puberty in adolescents. The cause of early puberty is the hormone estrogen. This hormone is known to play a role in regulating female sexual development.

The respondents were basically in their teens. Wirawan (2002: 23) explains that adolescents in Indonesia use the age limit of 11-24 years and are not married with the following considerations: (1) 11 years of age is the age at which secondary signs generally begin to appear, (2) In Indonesian society, 11 years of age are considered mature, both according to custom and religion, so that people no longer treat them as children, (3) At that age there are signs of perfecting mental development such as achieving ego identity (according to Ericson ), reaching the genital phase of psychosexual development (according to Freud), and reaching the peak of cognitive (according to Piaget), and moral (according to Kohlberg), (4) The age limit of 24 years is the maximum limit, namely to provide opportunities for those who arrive the age limit is still dependent on parents, does not have full rights as parents, (5) In this definition, marital status is very important whether the individual is still classified as a teenager or not. One of the research subjects has now exceeded the age limit of 24 years and has now gone through a period of storm and pressure so that this subject can think more mature.

\section{$>$ The level of the subject's religiosity is low}

The result of this research is from deepening the respondent's data that generally the level of religiosity is low. This is a problem faced during adolescence, namely the transition period which makes adolescent emotions less stable. This period is often referred to as a period of hurricane ("strum and drang)", namely a time of turmoil due to conflicting values. This transitional period has led to a tendency for deviant behaviors or what is commonly referred to as juvenile delinquency. Psychologically, juvenile delinquency is a form of conflicts that are not resolved properly in childhood and adolescence. This requires a strong belief and practice of religious teachings in order to reduce these delinquent behaviors. Palupi's research (2013) shows that the higher the religiosity, the lower the juvenile delinquency behavior. Examples of juvenile delinquency that have exceeded the limit are promiscuity in the form of risky sexual behavior. According to Pratiwi (2004), one of the causes of adolescents to engage in risky sexual behavior is experience and religious values. Adolescents who have a strong appreciation of religious values, good integrity also tend to be able to display sexual behavior in line with the values they believe in and seek satisfaction from productive behavior. In the case of this research, the subject's understanding and practice of religious values is very weak. Although some of them had studied at a boarding school during junior high school, they failed to understand. Among the respondents there were those who recited the Koran / went to recitation / or read the Koran. However, some of the subjects said that they read it without any meaning. In the respondent, there is a feeling of guilt / fear that is more oriented towards parents rather than fear of God.

Palupi (2013) formulates aspects of religiosity, namely: (1) aspects of belief or aqidah, this aspect relates to how much a person believes in his religious teachings, especially in fundamental teachings. (2) aspects of worship (religious practice), this aspect relates to the level of obedience of a person in carrying out ritual activities as ordered or recommended by his or her religion. (3) the practice aspect, this aspect relates to how a person feels and experiences religious feelings and experiences. (4) aspects of knowledge or knowledge, this aspect relates to how knowledgeable and understanding a person is of his religious teachings. (5) experience aspect, this aspect relates to how a person behaves in a manner motivated by his teachings. From the description above, it can be concluded that there are five aspects of religiosity, namely aspects of belief, worship, practice, knowledge and aspects of experience. In this case, the research subjects still have a fairly good belief in religion, sometimes worship, social practices, religious knowledge through educational institutions, and experiences in worshiping from childhood to early adolescence. 


\section{* Sufistic Counseling To Help Students Do Not Conduct Risk Sex Behavior}

Sufistic counseling is carried out in an effort to provide changes to students not to engage in risky sexual behavior. The counseling is based on Sufism values. Basically, students with risky sexual behavior do not adhere to any Sufism. In counseling students with risky sexual behavior who are Muslim, the values of Sufism are extracted from the results of in-depth interviews. This Sufism counseling method explores the values of Sufism in students who have risky sexual behavior who are Muslim so that they are able to perform tawazun (balancing) between fulfilling the interests of the hereafter and the interests of the world. This individual is expected to be able to formulate Islamic teachings in social life. Therefore Sufism employs a kasf epistemology which is considered as a level of processes that are intellectual in nature, which essentially try to incorporate into the moral, puritanical and social ethos. The implication of Sufism values in counseling is actually a scientific counseling concept that is required to be more humanistic, empirical and functional (appreciation of Islamic teachings). So that this counseling discusses and discusses how to build the morale of the people.

The stages of the implications of Sufism values in counseling in this study are divided into two stages, namely:

\section{$>$ Futuwwah}

At this stage, the counselor discusses with the counselee (risky sexual behavior) to find attitudes that try to erase arrogance, patience and steadfastness towards trials, and sincerity because of Allah SWT. The counselee tries to realize this futuwah stage as building an inner foundation so that he is willing to sacrifice everything he has, including life as a very valuable property. The counselee realizes that all matters are basically contained in one's spiritual (esoteric) sacrifice. So it would be nice if the counselee is able to do it, because if not, he realizes dealing with the futility of life.

Futuwah here can be represented by the zuhud nature of the counselee. The meaning of zuhud here is not only defined as an anti-world or anti-material attitude, but an attitude based on any nature of ownership including oneself. Humans must have a chivalrous nature that they must be sincere in all the risks that occur in life. Thus the human soul will be strong, able to erase the sense of arrogance, arrogance and pride in oneself. His soul will be educated zuhud in the sense of being simple, starting from the nature of sacrifice to himself and a material.

\section{Al-Itsar}

At this stage, the counselor discusses with the counselee (risky sexual behavior) to find al-Itsar's attitude, which is to consider others rather than himself. In practice, this attitude is reflected in a sincere concern (great concern) for people who have experienced disaster, or people who are persecuted. If futuwwah has more emphasis on individual impacts, then al-itsar has social impacts.
The counselee is expected to have an attitude to prioritize brotherhood, where this trait will strengthen one's faith and social life, be concerned with others because of piety. The purpose of giving priority to others towards oneself is a humanizing attitude. However, this is not only in the human sphere but in all life on earth, because humans are caliphs on earth.

With the attitude of al-itsar, the counselor carries out a movement that starts from inner strength towards social life. Where this inner strength begins with the nature of volunteering yourself to fully serve. If the counselee understands himself, it is expected that the counselee will be able to wrestle with various levels of society, serve fully because of Allah's orders.

Based on this, it can be understood that the implications of Sufism values in counseling begin with a futuwwah framework by applying a zuhud attitude which not only leaves an exaggerated attitude towards the macrocosmic world but also in the microcosmic world (humans). The stages: (1) takhalli (cleansing the heart from reprehensible traits). (2) tahalli (adorn oneself with praiseworthy qualities). Namely, the counselee is equipped with al-itsar characteristics, namely social characteristics that are supportive, helpful, generous, compassionate and other good qualities. (3) the tajalli stage, after these two stages with the basis of mental (esoteric) cultivation, a person will be able to organize himself and then be able to have a good social life so that he will achieve a perfect (happy) life. The implication of Sufism values in counseling, as an effort to cleanse the soul, educate, and increase the degree, mind, emphasize all trials and possessions and fight excess lust from the need to maintain self-peace. So that it will achieve a joy in living life.

The results of this study explain that Sufistic counseling by exploring the values of Sufism in counseling students with risky sexual behavior, also uses modern Sufism values conceptualized by Hamka. The core values of Hamka's Sufism Sufism are as follows: First, tauhīd, in the purest sense of divinity, which does not allow mythology towards nature and fellow humans. This includes culturism that is practiced by many Muslims. Second, personal responsibility in understanding religion. That is, one cannot "surrender" to the authority of others no matter how high their knowledge is - in the form of blind imitation. Third, taqarrub, by living up to the best possible meaning of worship that has been established by religion, and through that worship get as close to Allah as possible. Fourth, morals al-karīmah or noble character. Fifth. as a continuation of the morality of al-karimah, we are required to be actively involved in social life. Having religion seriously does not mean having to give up worldly life, but instead it should encourage to take part in joint efforts to improve society. In connection with this matter he said, "Filling a person with the qualities that exist in God, namely His attributes, which we can make our nature, according to our abilities. Sufism but not rejecting life. Sufism, then merging into in the community arena (Madjid, 1973: 131-132). " 


\section{CONCLUSIONS AND RECOMMENDATIONS}

Based on the results of data analysis, the conclusions are explained, among others 1) the psychological dynamics of risky sex offenders. First, the subjects were teenagers. Respondents aged between 22-24 years. The three subjects were in adolescence. Second, the level of the subject's religiosity is low. The results of this research from the deepening of the subject's data generally have a low level of religiosity where one problem faced during adolescence is the transition period which makes adolescent emotions less stable; 2) Sufistic counseling Sufistic counseling to help students not engage in risky sex behavior based on Sufism values in counseling is required to be more humanistic, empirical and functional (appreciation of Islamic teachings). So that this counseling discusses and discusses how to build the morale of the people. Sufism values in counseling lead to constructive coaching, both concerning personal and social life such as risky sexual behavior. Sufism values in counseling for students with risky sexual behavior include: (1), moral enhancement, (2) mortal in absolute reality, Sufism is a spiritual ascent to God, the Supreme Being, (3) direct intuitive knowledge from God, (4) happiness and tranquility of the soul, control of lust, purification of the soul, and various things done by individuals encourage the fading of fear and at the same time create peace of the soul, (5) the use of symbols in various expressions of love for God.

Based on the conclusions of the research results, the suggestions put forward include 1) the counseling method of Sufism has been carried out in stages effectively to increase the ability of students to behave in risky sexual behavior in takhalli, tahalli, and tajalli processes; 2) The application of Sufism needs to pay attention to the available resources, namely counselors in order to obtain the expected results. The counselor should improve communication and negotiation skills by adjusting various technological advances in order to remain competent in their field.

\section{REFERENCES}

[1]. Barjat, T. Raia. "Health students' knowledge of sexually transmitted infections andrisky behaviors before participation to the health promotion program". Médecine et maladies infectieuses xxx (2020) Xxx$\mathrm{xxx}$

[2]. Birthrong, Alex. "Aspects of impulsivity are differentially associated with risky sexual behaviors". Elsevier Personality and Individual Differences xxx (2013) xxx-xxx, (1-6).

[3]. Bryan, A. D., \& Stallings, M. C. (2002). A case control study of adolescent risky sexual behavior and its relationship to personality dimensions, conduct disorder, and substance use. Journal of Youth and Adolescence, 31(5), 387e396. http://dx.doi.org/10.1023/a:1015632709461
[4]. Chandra, D. A.,Rahmawati, I \& Hardiani,R. S.(2014). Hubungan Tipe Kepribadian dengan Perilaku Seksual Berisiko Remaja Di SMKN X Jember. Jurnal Pustaka Kesehatan Vol 2No 3 September 2014.

[5]. Damami, Mohammad. 2000. Tasawuf Positif Dalam Pemikiran HAMKA. Yogyakarta: Fajar Pustaka Baru.

[6]. Hamka. 2015. Tasawuf Modern.Jakarta: Republika.

[7]. Kasim, F.,2014. Dampak Perilaku Seks Berisiko terhadap Kesehatan Reproduksi dan Upaya Penanganannya (Studi tentang Perilaku Seks Berisiko pada Usia Muda di Aceh). Jurnal Studi Pemuda, pp. 3(1) : 39-48.

[8]. Luthviatin, N., Zulkarnain, E., Istiaji, E., Rohkmah, D., et al. (2012). Dasar-dasar Promosi Kesehatan dan Ilmu Perilaku. Jember:Jember University Press

[9]. Sarwono, W.S. 2013. Psikologi Remaja. Jakarta: Grafindo Persada

[10]. Sarwono. 2011. Psikologi Remaja. Edisi Revisi. Jakarta: Rajawali Pers.

[11]. Solihin. 2005. Melacak Pemikiran Tasawuf Di Nusantara, Jakarta: PT Rajagrafindo Persada. Pustaka Pelajar.

[12]. Syukur, M. Amin. 2004. Tasawuf Sosial. Yogyakarta: Pustaka Pelajar. 